\title{
Do We Successfully Achieve Therapeutic Hypothermia?
}

\author{
Woo Jeong Kim, M.D., Ph.D.
}

Department of Emergency Medicine, Jeju National University Hospital, School of Medicine, Jeju National University, JeJu, Korea

Treatment for cardiac arrest (CA) primarily focuses on restoring spontaneous circulation, after which further interventions are performed to achieve the best possible neurological outcome and to ultimately enable CA patients to resume their normal daily activities. As an attempt to reduce brain damage, the 2010 International Consensus on Cardiopulmonary Resuscitation and Emergency Cardiovascular Care Science with Treatment Recommendations recommended the use of therapeutic hypothermia (TH) $\left(32-34^{\circ} \mathrm{C}\right.$ for $12-24$ hours) for patients who achieve return of spontaneous circulation, but remain unconscious.[1]

The recommendation for $\mathrm{TH}$ is largely based on the results of two randomized, prospective studies. One of these studies involved the use of a mattress to deliver cold air and ice packs to induce $\mathrm{TH}$ at $32-34^{\circ} \mathrm{C}$ for 24 hours in five European countries. After TH, rewarming was performed slowly. Fifty-five percent of the hypothermia group demonstrated good neurological outcome, whereas only $39 \%$ of the control group exhibited good neurological outcome.[2] In another study conducted in Australia, ice packs were placed around the head and body of patients to induce $\mathrm{TH}$ at a targeted temperature of $33^{\circ} \mathrm{C}$ for 12 hours, and active rewarming began at 18 hours. Induced TH resulted in improved neurological outcome in $49 \%$ of the hypothermia group, while the same outcome was seen in only $26 \%$ of the control group.[3] In these two studies, induced TH effectively improved neurological outcome in patients with ventricular fibrillation out-of-hospital cardiac arrest. However, it has not yet been established whether TH is an effective treatment strategy for CA patients presenting with nonshockable rhythm, such as pulseless electric activity and asystole.[4,5] In addition, researchers are divided in their opinions on various elements of TH, including appropriate target temperature, cooling methods and period, and rewarming speed, calling for further studies.

When performing $\mathrm{TH}$, we strive to take a simple and minimally invasive approach in order to cool the body quickly and easily. External cooling techniques such as cooling blankets and helmets or ice bags are typically used at the beginning of treatment. Endovascular cooling has also been used to provide faster cooling and a steady maintenance phase via a cooling catheter introduced into the central venous system and a water-circulating cooling device. Different cooling methods vary in times of initiation of cooling, achievement of the target temperature and maintenance of TH. However, neurological recovery and mortality rates do not appear to vary significantly based on the cooling method used.[6,7] Recently, amid increasing recognition of its fast cooling effect, a large-volume $(30 \mathrm{~mL} / \mathrm{kg})$, ice-cold $\left(4^{\circ} \mathrm{C}\right)$ intravenous fluid infusion is widely used in the early stage of TH along with other cooling methods.[8]

Rates of cooling and rewarming are the most important factors to consider when performing

\section{Woo Jeong Kim}

Department of Emergency Medicine, Jeju National University Hospital, School of Medicine, Jeju National University, 15 Aran 13-gil, Jeju 690-767, Korea

Tel: +82-64-717-1921

Fax: +82-64-717-1079

E-mail: gurum21@jejunuh.co.kr

ORCID

Woo Jeong Kim http://orcid.org/0000-0002-8269-4581

* No potential conflict of interest relevant to this article was reported. 
TH. Although most cooling methods aim to achieve TH quickly at a targeted temperature, there was no significant difference in neurological outcome between early and late initiation of TH. However, a higher mortality rate was observed in patients who received early TH compared to those who received late TH.[9] Delay to target temperature adversely affects neurological outcome, however; thus, reaching target temperature as quickly as possible is important once the decision is made to use TH.[10] While neurological outcomes are not affected by differences in rewarming speed,[11] international guidelines support controlled rewarming at a rate of $0.25-0.5^{\circ} \mathrm{C} / \mathrm{hr}$.

The target temperature recommended is $32-34^{\circ} \mathrm{C}$ during $\mathrm{TH}$. As recently developed cooling techniques are able to achieve high target temperature accuracy, international guidelines for target temperature should be more specific. Patients who received $\mathrm{TH}$ of $32^{\circ} \mathrm{C}$ demonstrated better outcomes than those who received $\mathrm{TH}$ of $34^{\circ} \mathrm{C}$, suggesting the need for further studies on target temperature and potential revision of the recommended target temperature.[12]

Although $\mathrm{TH}$ could help reduce brain damage, prediction of neurological outcome in patients who survive CA remains a challenge. In general, pupillary reactions and corneal reflexes are examined and motor responses are assessed during neurological examination. In addition, electroencephalography and somatosensory evoked potential[13] are used for electrophysiological tests. Creatine kinase BB isoenzyme, neuron specific enolase,[14] S-100B protein,[15] lactate dehydrogenase, procalcitonin and lactate are commonly used as biomedical markers. Computed tomography, diffusion-weighted magnetic resonance imaging (MRI) and functional MRI are commonly used for neuroimaging. These tools can be useful for estimating neurological prognosis, but there is not optimal tool to predict prognosis yet.

In 2011, Korean hospitals that provide $\mathrm{TH}$ implemented a new TH protocol and shared their experiences through the Korean Hypothermia Network. Further studies are expected on $\mathrm{TH}$ treatment via the enhanced data collection and joint research opportunities provided through this nationwide network.

\section{References}

1) Morrison LJ, Deakin CD, Morley PT, Callaway CW, Kerber RE, Kronick SL, et al: Part 8: advanced life support: 2010 international consensus on cardiopulmonary resuscitation and emergency cardiovascular care science with treatment recommendations. Circulation 2010; 122: S345-421.

2) Hypothermia after Cardiac Arrest Study Group. Mild ther- apeutic hypothermia to improve the neurologic outcome after cardiac arrest. N Engl J Med 2002; 346: 549-56.

3) Bernard SA, Gray TW, Buist MD, Jones BM, Silvester W, Gutteridge G, et al: Treatment of comatose survivors of out-of-hospital cardiac arrest with induced hypothermia. N Engl J Med 2002; 346: 557-63.

4) Lundbye JB, Rai M, Ramu B, Hosseini-Khalili A, Li D, Slim $\mathrm{HB}$, et al: Therapeutic hypothermia is associated with improved neurologic outcome and survival in cardiac arrest survivors of non-shockable rhythms. Resusciatation 2012; 83: 202-7.

5) Dumas F, Grimaldi D, Zuber B, Fichet J, Charpentier J, Pène F, et al: Is hypothermia after cardiac arrest effective in both shockable and nonshockable patients?: insights from a large registry. Circulation 2011; 123: 877-86.

6) Heard KJ, Peberdy MA, Sayre MR, Sanders A, Geocadin $\mathrm{RG}$, Dixon SR, et al: A randomized controlled trial comparing the arctic sun to standard cooling for induction of hypothermia after cardiac arrest. Resuscitation 2010; 81: 9-14.

7) Gillies MA, Pratt R, Whiteley C, Borg J, Beale RJ, Tibby SM: Therapeutic hypothermia after cardiac arrest: a retrospective comparison of surface and endovascular cooling techniques. Resuscitation 2010; 81: 1117-22.

8) Virkkunen I, Yli-Hankala A, Silfvast T: Induction of therapeutic hypothermia after cardiac arrest in prehospital patients using ice-cold Ringer's solution: a pilot study. Resuscitation 2004; 62: 299-302.

9) Italian Cooling Experience Study Group: Early-versus lateinitiation of therapeutic hypothermia after cardiac arrest: preliminary observations from the experience of 17 Italian intensive care units. Resuscitation 2012; 83: 823-8.

10) Sendelbach S, Hearst MO, Johnson PJ, Unger BT, Mooney MR: Effects of variation in temperature management on cerebral performance category scores in patients who received therapeutic hypothermia post cardiac arrest. Resuscitation 2012; 83: 829-34.

11) Bouwes A, Robillard LB, Binnekade JM, de Pont AC, Wieske L, Hartog AW, et al: The influence of rewarming after therapeutic hypothermia on outcome after cardiac arrest. Resuscitation 2012; 83: 996-1000.

12) Lopez-de-Sa E, Rey JR, Armada E, Salinas P, Viana-Tejedor A, Espinosa-Garcia S, et al: Hypothermia in comatose survivors from out-of-hospital cardiac arrest: pilot trial comparing 2 levels of target temperature. Circulation 2012; 126: 2826-33.

13) Tiainen M, Kovala TT, Takkunen OS, Roine RO: Somato- 
sensory and brainstem auditory evoked potentials in cardiac arrest patients treated with hypothermia. Crit Care Med 2005; 33: 1736-40.

14) Tiainen M, Roine RO, Pettilä V, Takkunen O: Serum neuron-specific enolase and S-100B protein in cardiac arrest patients treated with hypothermia. Stroke 2003; 34: 2881-6.
15) Hachimi-Idrissi S, Zizi M, Nguyen DN, Schiettecate J, Ebinger G, Michotte Y, et al: The evolution of serum astroglial S-100 beta protein in patients with cardiac arrest treated with mild hypothermia. Resuscitation 2005; 64: 187-92. 